\title{
Social Support, Religiosity, and Health Literacy as Predictors of Resilience in Pregnant Women during COVID- 19 Pandemic
}

\author{
Nora Devi Irianjani \\ Master of Professional Clinical \\ Psychology, Faculty of Psychology \\ Universitas Ahmad Dahlan \\ noradevii@yahoo.com
}

\author{
Elli Nur Hayati \\ Faculty of Psychology \\ Universitas Ahmad \\ Dahlan \\ elli.hayati@psy.uad.ac.id
}

\author{
Ma Teresa De Guzman \\ Department of Behavioral Sciences, \\ College of Arts and Sciences \\ University of the Philippines Manila \\ mgdeguzman3@up.edu.ph
}

\begin{abstract}
Being pregnant during pandemic is challenging for women. A long and uncertain pandemic condition is accompanied by changes in health services, and other life conditions that require adaptation, coping, and resilient. This study aimed to examine the role of social support, religiosity, and health literacy as predictors of resilience among pregnant women during the COVID-19 pandemic in Yogyakarta, Indonesia. A purposive random sampling was employed to select participants of the survey, which was pregnant women that attended in antenatal care in Primary Health Care in Yogyakarta region. The scales of resilience, social support, religiosity, and health literacy was carried out to collect the data. Results showed that social support has a more significant contribution than health literacy and religiosity on resilience of pregnant women. Overall, there is a suitable health literacy mediation model between social support and resilience and religiosity with resilience. Social support, health literacy, and religiosity can be the predictors of resilience.
\end{abstract}

Keywords: COVID-19, pregnant women, resilience

Received 27 November 2021/Accepted 28 February 2022 @Author all rights reserved

\section{Introduction}

COVID-19 is a new variant virus first reported in Wuhan, China in December 2019 and confirmed by World Health Organization (WHO) later (Hassan et al., 2020). According to World Health Organization (World Health Organization, 2020), the coronavirus (COVID-19) caused a severe acute respiratory syndrome and had spread rapidly around the world. On March 12, 2020, the World Health Organization announced that the pandemic has hit almost all parties and even sectors of society (Zhang \& Liu, 2020). The current COVID-I9 pandemic has become a 
severe global crisis, which is currently out of control. COVID-19 is developing rapidly worldwide, and its mortality rate is increasing day by day. There are several groups of high risk people being infected by COVID-19, particularly people with comorbidities, people with obesity, the elderly, and pregnant women (Pradana, 2020).

According to data from the Indonesia National Population and Family Planning Agency (2020), the prevalence of pregnancy increases during the pandemic, due to the decline services at the Primary Health Center, including antenatal care. There was significant increase in pregnancies in several regions, especially in Yogyakarta. The prevalence of pregnant women increased by $41.74 \%$ compared to the previous year (2020). The conditions of the COVID-19 pandemic have a critical influence on pregnant women. Physiological changes during pregnancy cause pregnant women more vulnerable in the pandemic situation. Physiological changes during pregnancy can cause partial miscarriage; so there are more susceptible to viral infections (Pradana, 2020). Meanwhile, pregnant women have immune system changes that can lead to reduced immunity, which increases the sensitivity to intracellular pathogens such as viruses, leading to an increase in the overall infection rate (Dashraath et al., 2020).

The physiological susceptibility in pregnant women is proven by the number of positive infected among pregnant women more than non-pregnant women (CDC COVID-19 Response Team et al., 2020). Pregnant women who infected with COVID-I9 have symptoms of respiratory disease, which can aggravate pregnancy (Brooks et al., 2020). This situation makes pregnant women need to be treated in the intensive care unit and receive respiratory assistance (www.who.int, 202I). Covid 19 does not only affects the physical condition and the inability to deal with stressful conditions but also dysregulation in nervous system (Long et al., 2020). The pandemic condition may also cause psychological distress, including stress, anxiety, and depression. A study reported that depression and anxiety rate among pregnant women after the announcement of the COVID-19 were higher than before the announcement, including the tendency to self-harm among women ( $\mathrm{Wu}$ et al., 2020). All the risks and changes in health services that pregnant women experiences during the pandemic have negative consequences.

During this pandemic years, many countries implement travel bans and non-emergency medical 
services to focus on the availability of resources for treating COVID-19 patients (www.who.int, 2021). According to the Indonesian Ministry of Health data, the availability of health service has also reduced for ordinary patients (non-COVID- 19 patients), in order to preventing the COVID19 contagions and reducing it (Puskapik, 2020).

Based on several explanations above, it can be concluded that pregnant women are high-risk people with high vulnerability and extreme conditions during a pandemic. The existence of personal strength can help pregnant women face challenges events during the pandemic; therefore, it does not negatively impact both the individual and the fetus (Matvienko-Sikar, et al, 2020).

Resilience is considered as the foundation of the basic strength or positive character that builds a person's emotional and psychological strength (Mosheva, et al, 2020). Resilience leads to a dynamic adaptation process, so it can originate from adverse life experiences and compromise when faced with stressful situations (Torabizadeh et al., 2019). Indeed, Preis et al. (2020) explained that resilient pregnant women could overcome various life problems in their way when encountering problems. Resilience plays an important role, so individuals will not be stressed. Several studies have shown that people with low resilience are prone to high distress (Mosheva et al., 2020; Polizzi et al., 2020). Women who had a higher level of perceived stress and a lower level of resilience had a higher rate of prenatal depression (Zhang et al., 2020).

Psychologically, increasing the immune system of pregnant women can also be achieved by providing social support (Friedman, 2020). The received social support can affect the degree of anxiety of the individual because it cannot be denied that the psychosocial changes during pregnancy affect the emotional state (Gao et al., 2020). Apart from social support, Rostiani, Toyib, \& Khoiriyah (202I) explained that religiosity is one factor that affects resilience. It is believed that religious activities can promote the adaptability of individuals (including pregnant women) during the COVID-19 pandemic. Multiple studies have emphasized the role of religiosity in coping, which may affect the outcome of physical and mental illness (Amadi et al., 2016). One of the crucial things that should be achieved during the pandemic is that people should get well information about the pandemic and health. Well informed on health means that the individual 
has a good health literacy. Health literacy is conceptualized as the skills required to understand and apply health information in daily life (Karimi et al., 202I).

Studies that focus on the mental health of pregnant women who faced challenges in this pandemic situation is still limited. Therefore, the current study will explore this topic that has not been studied before.

\section{Method}

\section{Participants}

The population of the study was pregnant women in Yogyakarta, Indonesia. Purposive non probability sampling was carried out, and researcher was involved in selecting individuals who fit with the research criteria. This criteria useful for understanding the phenomenon (Creswell, 2014). A total of 230 participants that registered from several Primary Health Cares in Yogyakarta were recruited and consented to participate the study, Participant's age was ranged from 20 to 35 years, $60 \%$ had more than twelve years (> 12 years) education, $95 \%$ were Muslim, $24 \%$ were pregnant at first trimester, $32 \%$ were second trimester, and $44 \%$ at the third trimester (see Table I).

Table I

Research Subject Demographic Analyst Results

\begin{tabular}{llcc}
\hline No & Category & Amount & Percentage (\%) \\
\hline I. & Education & & \\
\cline { 2 - 4 } & SMP (Junior High School) & 15 & $7 \%$ \\
& SMA (Senior High School) & 74 & $33 \%$ \\
& D3 (3-year Diploma) & 18 & $8 \%$ \\
& S1 (Bachelor degree) & 105 & $46 \%$ \\
& S2 (Master degree) & 13 & $6 \%$ \\
\hline 2. & Religion & 215 & $95 \%$ \\
\cline { 2 - 4 } & Islam & 6 & $3 \%$ \\
& Catholic Christian & 3 & $1.2 \%$ \\
& Christian Protestant & 2 & $0.8 \%$ \\
\hline
\end{tabular}




\begin{tabular}{llcc}
\hline No & Category & Amount & Percentage (\%) \\
\hline 3. & Gestational age & & \\
\cline { 2 - 4 } & $1^{\text {st }}$ Trimester & 57 & $24 \%$ \\
& $2^{\text {nd }}$ Trimester & 73 & $32 \%$ \\
& $3^{\text {rd }}$ Trimester & 100 & $44 \%$ \\
\hline
\end{tabular}

\section{Measure}

The resilience scale (CD-RISC)

The CD-RISC consisted of 22 items and was adapted from Kurniawan \& Noviza (20I8). To adapt the CD-RISC, we primarily modified general conditions into a COVID-19 pandemic and replaced participant criteria. Content validation using Aiken's $V$ scores ranges from $0.66-0.9 \mathrm{I}$ and the Cronbach's alpha reliability coefficient is 0.898 . A sample item is "During pregnancy, I was able to adjust to the changes that occurred during the COVID-19 pandemic". Each item is rated on a 5-point Likert scale of I (never) to 5 (always). A total score can be calculated by summing all 22 items, so that the scores ranged from 22 to 110 . Higher score indicates higher levels of resilience related to COVID- 19.

\section{Social Support Scale}

The social support scale has four aspects: emotional, instrumental, information, and reward (Sarafino \& Smith, 20I4). The result of content validation using Aiken's V scores ranges from 0.63-0.92, and the Cronbach's alpha reliability coefficient was 0.883 . The social support consists of I5 items; each item is rated on a 4-point Likert scale from I(never) to 4 (very often). An example item is "I receive suggestions from people closest to maintaining a healthy pregnancy." Additional item, which requires a description of the answer "As a pregnant woman during the COVID-19 pandemic, in your opinion, which social support is the most influential for you so far: Primary (husband, family members, and closest people) or Secondary (health institutions and professionals), Reason?". A total score can be calculated by summing all 15 items and such that scores can range from 15 to 60 , with higher scores on the total social support scale showing greater social support related COVID-19.

Religiosity Scale 
The religiosity scale consists of 18 items, with five aspects: ideological, ritualistic, experience, intellectual, and consequential (Huber \& Huber, 2012). The result of content validation using Aiken's $V$ scores ranges from 0.59-0.94, and the Cronbach's alpha reliability coefficient was 0.948. Each item is rated on a 4-point scale from I (strongly disagree) to 4 (strongly agree). An example item is "I feel calm when I remember the rizki (wealth, health, harmonious family, etc.) that God has given in my life." A total score can be calculated by summing all 18 items and such that scores can range from 18 to 72 , with higher scores on the religiosity scale indicating greater religiosity.

\section{HLS-EU-I 6 (Health Literacy Survey-Europe-I 6 Questions)}

The HLS-EU-Q questionnaire consists of 16 items with a Likert scale. In this study, the HLS-EUQ16 questionnaire was used adopted from AHLA Indonesia as the official license holder of the questionnaire and has been used with the Indonesian version ((HLS-EU) (Consortium Health Literacy Project European et al., 2012). The result of content validation using Aiken's $V$ scores ranges from $0.71-0.89$, and the Cronbach's alpha reliability coefficient was 0.932 . Each item is rated on a 4-point scale from I (very difficult) to 4 (effortless). An example item is "Understanding health information related to the myths and facts of pregnancy and pandemic COVID-19, such as things that are recommended and not recommended during the pandemic period". A total score can be calculated by summing all 16 items and such that scores can range from 16 to 64 . A higher score indicates higher levels of health literacy related to COVID-19.

\section{Procedure}

A secure scale form was used to develop an online version of the questionnaires prompted by an expert on social media and distributed offline by coordinating with the midwives of the primary health center in the research area. Participants were also contacted by messaging apps (e.g., WhatsApp) asking them for their involvement. Those who expressed their interests were provided a link that explain what matters involved in the study. If participants agreed, they were invited to read and accept an informed consent form presented on the first page of an online survey. They were not allowed to access the questionnaires until informed consent was signed. All participants voluntarily took part in the survey. 


\section{Data Analysis}

The statistical analysis used in this study was assisted by the IBM SPSS Amos Version 24 program. The data analysis method used in this study is path analysis, a further development of multiple and bivariate regression analysis. Path analysis is a technique that analyzes the causal relationship that occurs when a variable affects the dependent variable directly and indirectly.

\section{Ethical consideration}

Ethical approval of this study was obtained from the Medical and Health Research Ethics Committee (MHREC) Gadjah Mada University Ref. No. KE/FK/030I/EC/202I, date of approval on April 13, 2021.

\section{Result}

Categorical Description of The Data

The resilience categorization was divided into three, namely low, moderate and high. Table 2 shows that $13 \%$ of research subjects are in the moderate resilience category and as many as $87 \%$ in the high resilience category. The categorization of social support was divided into three, namely low, moderate and high. Next, $25 \%$ of the research subjects received moderate social support, and as many as $75 \%$ received high social support. These data indicate that the majority of pregnant women in the Yogyakarta area in high level of resilience and receive high social support.

Furthermore, majority of religiosity among women in this study (99\%) was in high category. Health literacy levels were categorized into three, namely low, moderate, and high. Meanwhile, $93 \%$ of the participants were in high level of health literacy. These data indicate that majority of pregnant women in Yogyakarta were in high level of religiosity as well as their health literacy. 
Table 2

The results of the categorization of the research subjects' scores

\begin{tabular}{llccc}
\hline Variable & Category & Interval Score & Total & Percentage \\
\hline Resilience & Low & $X<5$ I & 0 & $0 \%$ \\
& Moderate & $5 I \leq X<8$ I & 29 & $13 \%$ \\
& High & $8 I \leq X$ & 201 & $87 \%$ \\
\hline Social Support & Low & $<30$ & 0 & $0 \%$ \\
& Moderate & $30 \leq X<45$ & 57 & $25 \%$ \\
& High & $45 \leq X$ & 173 & $75 \%$ \\
\hline Religiosity & Low & $X<36$ & 0 & $0 \%$ \\
& Moderate & $36 \leq X<45$ & 1 & $1 \%$ \\
& High & $45 \leq X$ & 229 & $99 \%$ \\
\hline Health Literacy & Low & $X<38$ & 0 & $0 \%$ \\
& Moderate & $38 \leq X<46$ & 6 & $7 \%$ \\
& High & $46 \leq X$ & 214 & $93 \%$ \\
\hline
\end{tabular}

\section{Structural Equation Model}

The structural equation model (Figure I) was then carried out to examine the direct and indirect association between the variables. Conducted a review of various goodness of fit criteria and cut off value to test the model is acceptable, the model below meets the fit model criteria.

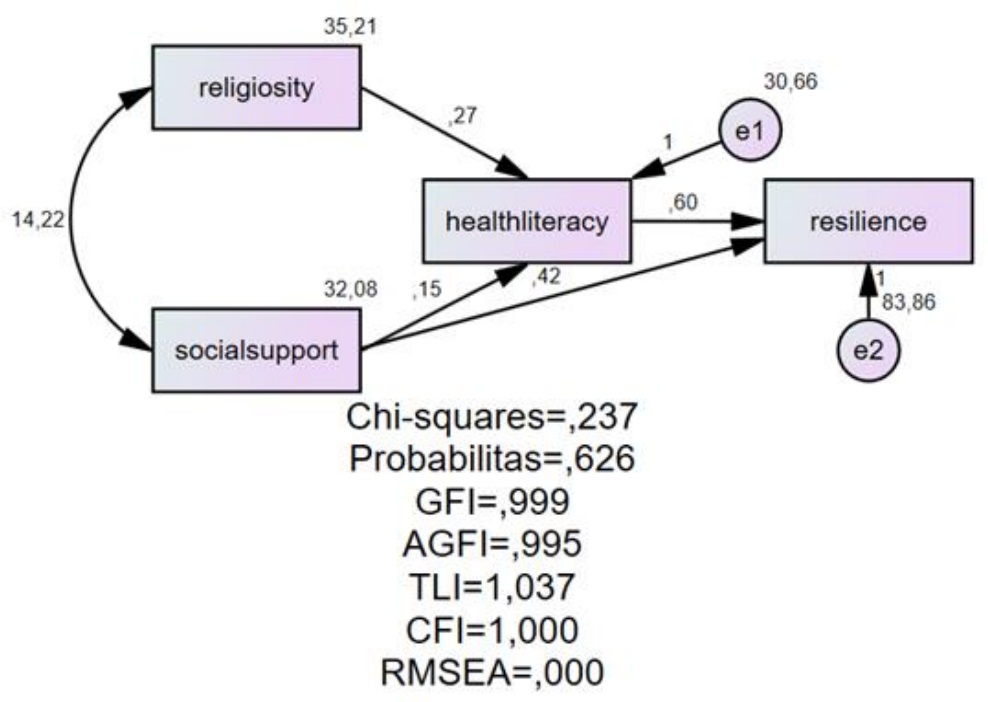

Figure I. Structural Equation Models 
The regression weight test result showed the coefficient of influence between the related variables.

The results of the data analysis showed that all the constructs used to form a research model (see Table 3).

Table 3

Regression Weights

\begin{tabular}{lrlrrrrl}
\hline \multicolumn{1}{c}{ Variable } & & & Estimate & S.E. & C.R. & P & Label \\
\hline Health Literacy & $\leftarrow-$ & Religiosity & 0.269 & 0.068 & 3.946 & $* * *$ & par_I \\
Health Literacy & $\leftarrow-$ & Social Support & 0.148 & $0.07 I$ & $2.07 I$ & 0.038 & par_2 \\
Resilience & $\leftarrow-$ & Health Literacy & 0.598 & 0.106 & 5.654 & $* * *$ & par_3 \\
Resilience & $\leftarrow-$ & Social Support & 0.423 & 0.111 & 3.824 & $* * *$ & par_5 \\
\hline
\end{tabular}

The results showed a direct relationship between social support and resilience and an indirect relationship between religiosity to health literacy than to resilience (Table 4). Social support positively affects resilience with a coefficient standard of 0.232 and is significant at a $p$-value of $1 \%$. Social support also has a positive effect on health literacy with a coefficient of $0.14 \mathrm{I}$ and a significant $\mathrm{P}$-value of $1 \%$, thus health literacy has a positive effect on resilience with a coefficient of 0.343 and a significant p-value of $1 \%$. Religiosity also positively affects health literacy with a standard coefficient of 0.269 and is significant at a $p$-value of $1 \%$.

Table 4

Standardized Regression Weights

\begin{tabular}{lclc}
\hline Variable & & & Estimate \\
\hline Health Literacy & $\leftarrow-$ & Religiosity & 0.269 \\
Health Literacy & $\leftarrow-$ & Social Support & 0.141 \\
Resilience & $\leftarrow-$ & Health Literacy & 0.343 \\
Resilience & $\leftarrow-$ & Social Support & 0.232 \\
\hline
\end{tabular}

As presented in table 5 , the R-Square of health literacy is 0.125 , results showed that the variability of health literacy can be explained by the variability of social support and religiosity of $12.5 \%$. At the same time, the R-Square resilience is 0.212 , showed that the variability of resilience can be 
explained by the variability of the three variables of social support, religiosity, and health literacy is $21.2 \%$.

Table 5

Squared Multiple Correlations

\begin{tabular}{lc}
\hline Variable & Estimate \\
\hline Health Literacy & 0.125 \\
Resilience & 0.212 \\
\hline
\end{tabular}

Standardized direct, indirect and total effect are reported in Table 6. The direct effect of social support on resilience is $\mathbf{0 . 2 3 2}$. The indirect effect of social support on health literacy then resilience is 0.048 . So, the total effect on resilience is 0.280 .

Table 6

Standardized Direct, Indirect, \& Total Effects

Standardized Direct Effects

Variable Social Support

Religiosity

Health Literacy

Health Literacy

0.141

0.269

0.000

Resilience

0.232

0.000

0.343

Standardized Indirect Effects

Variable

Health Literacy

Social Support

Religiosity

Health Literacy

0.000

0.000

0.000

Resilience

0.048

0.092

0.000

Standardized Total Effects

Variable

Social Support

Religiosity

Health Literacy

Health Literacy

0.141

0.269

0.000

Resilience

0.280

0.092

0.343

Furthermore, a bootstrapping procedure with 5,000 bootstrap samples was conducted to estimate indirect effect using 95\% confidence intervals. All analyses were run using SPSS and AMOS versions 24 for Windows. Bootstrapping was used to test the effectiveness of mediation by health literacy. 
Based on the analysis (as presented in Table 7) it showed that health literacy had significant effect in mediating social support with resilience and religiosity with resilience.

Table 7

Output Bootstrapping Standardized Direct-Indirect Effects - Two-Tailed Significance

\begin{tabular}{llll}
\hline \multicolumn{2}{l}{ Bootstrapping Standardized Direct Effects } & & \\
\hline & Social Support & Religiosity & Health literacy \\
Health literacy & 0.049 & 0.005 & 0.000 \\
Resilience & 0.014 & 0.000 & 0.004 \\
Bootstrapping Standardized Indirect Effects & & \\
& Social Support & Religiosity & Health literacy \\
Health literacy & 0.000 & 0.000 & 0.000 \\
Resilience & 0.035 & 0.002 & 0.000 \\
\hline
\end{tabular}

Additional analysis regarding social support showed that primary social support had dominant role for pregnant women during the COVID-19 pandemic, as answered by at least $66.5 \%$, compare to only $9.6 \%$ who report the importance of secondary social support (see Table 8).

Table 8

Distribution of Types of Social Support

\begin{tabular}{lcccc}
\hline \multicolumn{1}{c}{$\begin{array}{c}\text { Types of social } \\
\text { support }\end{array}$} & Frequency & Percent & Valid Percent & $\begin{array}{c}\text { Cumulative } \\
\text { Percent }\end{array}$ \\
\hline $\begin{array}{l}\text { Primary social } \\
\text { support }\end{array}$ & 153 & 66.5 & 66.5 & 3.5 \\
Secondary social & 22 & 9.6 & 9.6 & 79.6 \\
support & 8 & 3.5 & 3.5 & 3.5 \\
Blank & 47 & 20.4 & 20.4 & 100.0 \\
Both & 230 & 100.0 & 100.0 & \\
Total & & & & \\
\hline
\end{tabular}

The role of primary social support for pregnant women during the COVID-I9 pandemic came from their husbands, family members, and their closest people, while secondary social support came 
from health institutions and professional staff. The primary forms of social support received by pregnant women include tangible and emotional support, positive and optimistic messages, convenience treatment from the husband, helping to calm the mind, advices on maintaining the pregnancy, helping to ease homework, etc. The forms of secondary social support include monitoring the health of the mother and fetus, providing understanding and information related to health maintenance and overcoming pandemic problems, providing explanations and habituation amid a pandemic, etc.

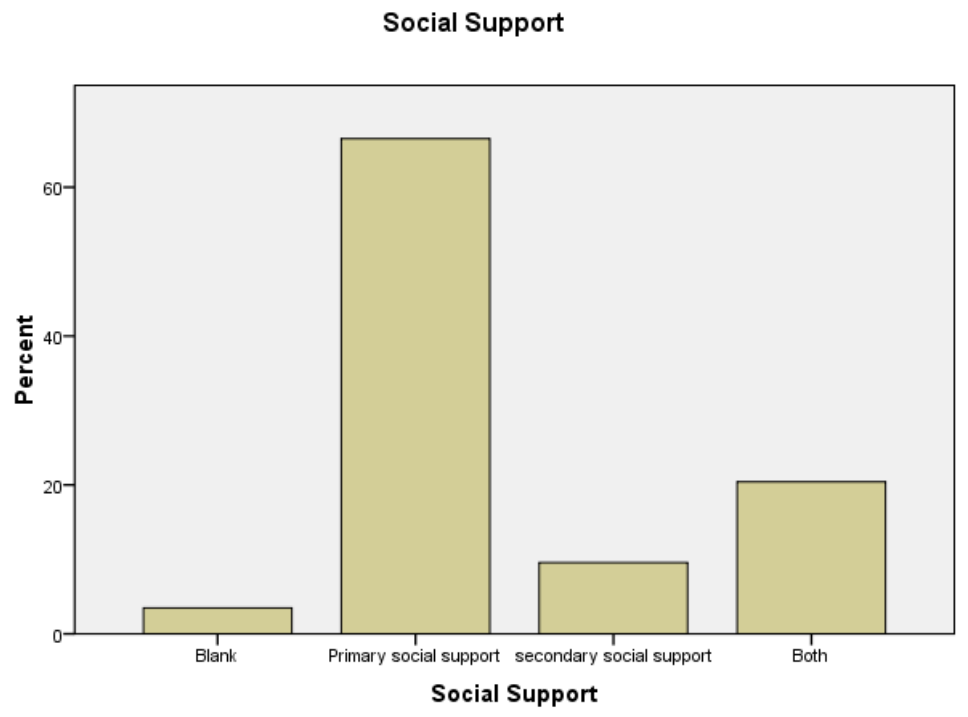

Figure 2. Distribution of Types of Social Support

\section{Discussion}

High resilience has helped pregnant women to overcome all problems during the pandemic, and effective ability to handle all conditions that cause anxiety to be less destructive. Specifically, pregnant women with high resilience tend to had lower perceived stress, pregnancy-specific stress, psychopathological symptoms, and higher psychological well-being (Garcia-Dia et al., 2013). This current study aligns with the previous findings that confirm individuals with high resilience are more likely to experience positive emotions (Yeo, 20II). Positive emotions might 
has helped pregnant women to be able to reduce negative emotions, so they can adapt optimally even though they are faced with the stressful demands of change or problems in life.

Result of this study showed that the level of resilience in pregnant women cannot be separated from the influence of personal and social factors. Those factors are individual factors, education, genetics, culture, and the individual's environment (Huey \& Palaganas, 2020). The study results also found an effect of social support on the resilience in pregnant women. Social support is an essential factor determining high and low resilience, including among pregnant women (Ong et al., 2018). Pregnant women who receive adequate social support will feel cared for, secure, calm, confident, and competent. It is further explained that individuals who receive high social support are theoretically better able to adapt and or modify external stressors, thus encouraging wellfunctioning psychosocial and self-adjustment. This relationship was further investigated in followup studies, showed that high social support can increase resilience among adults (O'Donnell et al., 2020). Based on some of the results of similar research, it can be interpreted that the higher the social support received, the higher the level of individual resilience will be.

Indonesian people are adherents of communalism, means that people prefer to live in groups. A communal community considers social support as part of the interdependence that creates security and a sense of security. As Yogyakarta municipals is considered as communal, this might have caused high social support for pregnant women in this study. Communal relationships affect individual wellbeing, means that individuals who get sufficient social support will lead a more positive life so that they are healthier psychologically and physically (Clark \& Mills, 20I2). In this study, primary social support has more influence on the resilience of pregnant women.

The complexity of resilience makes it a critical thing to be taken into account and becomes a main topic of discussion in the area of health promotion (Vella et al., 202I). Health literacy is also related to the ability of individuals to interact with the health service system, education system, and various socio-cultural factors in the neighborhood, workplace, and society (Gautam et al., 202I). In this study, terms of health literacy related to the ability of pregnant women to seek and understand information about prenatal care, which is very important related to their health and the fetus. The level of individual health literacy cannot be separated from its relationship with 
social, cultural, and psychosocial support. The social support received by individuals from their surroundings play a role in increasing their health literacy (Liu et al., 2020). Social support is related to the health literacy of patients, where an increase in patient assistance will increase their health literacy (Andrianys et al., 20I7).

The effectiveness of health literacy as a mediating factor is evident in some literatures. Health literacy mediates social support and symptoms of depression; which means that low health literacy is related to a lack of knowledge in health issues, and this has caused to health problems (Stormacq et al., 2019). Apart from social support, the study results also showed that health literacy is influenced by religiosity. Health literacy is influenced by proficiency in the language, ethnicity or culture, religious beliefs, education, cognitive abilities, age, and social environment (Rowsell et al., 2015). Another study finding showed that health literacy can increase individual and community resilience (D'Eath, 20I2).

Previous studies suggest that religious involvement is associated with better mental health outcomes (Silva et al., 2016). The mediating role of health literacy in religiosity toward individual's resilience is proven to be effective, which means that religious individuals tend to be strive of being healthy in facing various conditions. In pregnant women, one of the efforts of being healthy is to have adequate health literacy. Religiosity increases health literacy skills, so this ability helps to increase resilience. Religiosity is always associated with positive mental health outcomes, including differences in psychological adaptability (Miller et al., 20I2).

Finally, result of this study showed that social support has a more significant effective contribution than health literacy and religiosity. This is indicated that the need of pregnant women for social support (from partners, family, friends, the environment, and health workers) is very high during the COVID-19 pandemic. Based on the explanation above, it is concluded that there is a suitable health literacy mediation model between social support and resilience, and religiosity with resilience. 


\section{Conclusion}

This study showed a direct relationship between social support and resilience, an indirect relationship from social support mediated by health literacy to resilience, and an indirect relationship from religiosity to health literacy. Social support has a more significant effective contribution than health literacy and religiosity; this is indicated that the need of pregnant women for support from partners, family, friends, the environment, and health workers is very high in the COVID-19 pandemic situation. The role of social support, religiosity, and health literacy on resilience are positive. The higher the social support received, the higher religiosity and health literacy possessed by pregnant women, especially during the COVID-I9 pandemic, the higher the level of their resilience. Overall, there is a suitable health literacy mediation model between social support and resilience and religiosity with resilience. This means that social support, health literacy, and religiosity can be the predictors of resilience.

\section{Acknowledgment}

The authors wish to express gratitude to the subjects who had been willing to participate in this research process. Our gratitude also goes to the Ministry of Education, Culture, Research \& Technology (Kemendikbudristek) of the Republic of Indonesia for the grant to take part in the International Credit Transfer program between the Study Program of Psychology Profession Universitas Ahmad Dahlan, Indonesia and the Department of Behavioral Science - University of The Philippines Manila.

\section{References}

Amadi, K. U., Uwakwe, R., Ndukuba, A. C., Odinka, P. C., Igwe, M. N., Obayi, N. K., \& Ezeme, M. S. (2016). Relationship between religiosity, religious coping and socio-demographic variables among out-patients with depression or diabetes mellitus in Enugu, Nigeria. African Health Sciences, /6(2), 497. https://doi.org//0.43/4/ahs.v16i2.18

Andrianys, I., Kadar, K., \& Massi, N. (2017). Precede-Proceed education model to health literacy's patient with hypertension in Pattingalloan Makassar. 8.

BKKBN. (2020): Jurnal Keluarga Berencana. (2020). Retrieved August 26, 2021, from 
https://ejurnal.bkkbn.go.id/kkb/issue/view/I I Vol. 5 No. 2

eBrooks, S. K., Weston, D., \& Greenberg, N. (2020). Psychological impact of infectious disease outbreaks on pregnant women: Rapid evidence review. Public Health, 189, 26-36. https://doi.org/10.1016/j.puhe.2020.09.006

CDC COVID-19 Response Team, CDC COVID-19 Response Team, Chow, N., Fleming-Dutra, K., Gierke, R., Hall, A., Hughes, M., Pilishvili, T., Ritchey, M., Roguski, K., Skoff, T., \& Ussery, E. (2020). Preliminary estimates of the prevalence of selected underlying health conditions among patients with coronavirus disease 2019-United States, February I2-March 28, 2020. MMWR. Morbidity and Mortality Weekly Report, 69(13), 382-386. https://doi.org/I0.15585/mmwr.mm69/3e2

Clark, M., \& Mills, J. R. (2012). A theory of communal (and exchange) relationships. Handbook of Theories of Social Psychology, 232-250. https://doi.org/I0.4I35/978I446249222.n38

COVID-19: Occupational health and safety for health workers. (2021). Retrieved August 26, 2021, from https://www.who.int/publications-detail-redirect/WHO-2019-nCoV-HCW_advice2021.1

Creswell, J. W. (20/4). (PDF) Book Review Research Design: Qualitative, Quantitative and Mixed Methods Approaches (4th ed.). Thousand Oaks, CA: Sage. (202I). Retrieved August 26, 202I, from

https://www.researchgate.net/publication/332246566_Book_Review_Creswell__W_20I4_ Research_Design_Qualitative_Quantitative_and_Mixed_Methods_Approaches_4th_ed_Th ousand_Oaks_CA_Sage

Dashraath, P., Wong, J. L. J., Lim, M. X. K., Lim, L. M., Li, S., Biswas, A., Choolani, M., Mattar, C., \& Su, L. L. (2020). Coronavirus disease 2019 (COVID-19) pandemic and pregnancy. American Journal of Obstetrics and Gynecology, 222(6), 52I-53I. https://doi.org/10.1016/j.ajog.2020.03.021

Durankuș, F., \& Aksu, E. (2020). Effects of the COVID-19 pandemic on anxiety and depressive symptoms in pregnant women: A preliminary study. The Journal of Maternal-Fetal \& Neonatal Medicine, I-7. https://doi.org/I0.1080/I4767058.2020.1763946

D'Eath, R. (20I2). Repeated locomotion scoring of a sow herd to measure lameness: Consistency over time, the effect of sow characteristics and inter-observer reliability. Animal Welfare, 2I(2), 219-23I. https://doi.org/I0.7I20/09627286.2I.2.219

Friedman, L. E., Gelaye, B., Sanchez, S. E., \& Williams, M. A. (2020). Association of social support and antepartum depression among pregnant women. Journal of Affective Disorders, 264, 20I205. https://doi.org/10.1016/j.jad.2019.12.017

Gao, L., Qu, J., \& Wang, A. Y. (2020). Anxiety, depression and social support in pregnant women with a history of recurrent miscarriage: A cross-sectional study. Journal of Reproductive and 
Infant Psychology, 38(5), 497-508. https://doi.org/I0.1080/02646838.2019.1652730

Garcia-Dia, M. J., DiNapoli, J. M., Garcia-Ona, L., Jakubowski, R., \& O’Flaherty, D. (20I3). Concept Analysis: Resilience. Archives of Psychiatric Nursing, 27(6), 264-270. https://doi.org/10.1016/j.apnu.2013.07.003

Gautam, V., S, D., Rustagi, N., Mittal, A., Patel, M., Shafi, S., Thirunavukkarasu, P., \& Raghav, P. (202I). Health literacy, preventive COVID 19 behaviour and adherence to chronic disease treatment during lockdown among patients registered at primary health facility in urban Jodhpur, Rajasthan. Diabetes \& Metabolic Syndrome: Clinical Research \& Reviews, I5(I), 20521 I. https://doi.org/10.1016/j.dsx.2020.12.023

Hassan, S. A., Sheikh, F. N., Jamal, S., Ezeh, J. K., \& Akhtar, A. (2020). Coronavirus (COVID-19): A review of clinical features, diagnosis, and treatment. Cureus. https://doi.org// 0.7759/cureus.7355

Herdiana, I. (2019). RESILIENSI KELUARGA: TEORI, APLIKASI DAN RISET. PSIKOSAINS (Jurnal Penelitian dan Pemikiran Psikologi), I4(I), I. https://doi.org// 0.30587/psikosains.v I4i I.889

Huber, S., \& Huber, O. W. (20I2). The Centrality of Religiosity Scale (CRS). Religions, 3(3), 7I0724. https://doi.org//0.3390/rel30307/0

Huey, C. W. T., \& Palaganas, J. C. (2020). What are the factors affecting resilience in health professionals? A synthesis of systematic reviews. Medical Teacher, 42(5), 550-560. https://doi.org//0.1080/0142159X.2020.17/4020

Karimi, A., Rafiei Tabatabaei, S., Shariatpanahi, G., Javadzadeh, M., Armin, S., \& Yeganeh, Z. (202I). Isolated Chronic Aseptic Meningitis Due to SARS-COV-2 Unresponsive to Ordinary Treatments. Archives of Pediatric Infectious Diseases, In Press(In Press). https://doi.org/I0.58I2/pedinfect.I I 3 I 75

Kurniawan, Y., \& Noviza, N. (20I8). Peningkatan resiliensi pada penyintas kekerasan terhadap perempuan berbasis terapi kelompok pendukung. Psikohumaniora: Jurnal Penelitian Psikologi, 2(2), I25. https://doi.org/10.21580/pjpp.v2i2.1968

Liu, Y., Meng, H., Tu, N., \& Liu, D. (2020). The Relationship Between Health Literacy, Social Support, Depression, and Frailty Among Community-Dwelling Older Patients With Hypertension and Diabetes in China. Frontiers in Public Health, 8, 280. https://doi.org// 0.3389/fpubh.2020.00280

Long, Q.-X., Liu, B.-Z., Deng, H.-J., Wu, G.-C., Deng, K., Chen, Y.-K., Liao, P., Qiu, J.-F., Lin, Y., Cai, X.-F., Wang, D.-Q., Hu, Y., Ren, J.-H., Tang, N., Xu, Y.-Y., Yu, L.-H., Mo, Z., Gong, F., Zhang, X.-L., ... Huang, A.-L. (2020). Antibody responses to SARS-CoV-2 in patients with COVID- I 9. Nature Medicine, 26(6), 845-848. https://doi.org/ I0.1038/s4 I 59I-020-0897-I

Matvienko-Sikar, K., Pope, J., Cremin, A., Carr, H., Leitao, S., Olander, E. K., \& Meaney, S. (2020). 
Differences in levels of stress, social support, health behaviours, and stress-reduction strategies for women pregnant before and during the COVID-19 pandemic, and based on phases of pandemic restrictions, in Ireland. Women and Birth, SI87I5I922030367X. https://doi.org/10.1016/j.wombi.2020.10.010

Miller, L., Wickramaratne, P., Gameroff, M. J., Sage, M., Tenke, C. E., \& Weissman, M. M. (20I2). Religiosity and Major Depression in Adults at High Risk: A Ten-Year Prospective Study. American Journal of Psychiatry, I69(I), 89-94. https://doi.org/10.I I76/appi.ajp.201 I.10121823

Mosheva, M., Hertz-Palmor, N., Dorman Ilan, S., Matalon, N., Pessach, I. M., Afek, A., Ziv, A., Kreiss, Y., Gross, R., \& Gothelf, D. (2020). Anxiety, pandemic-related stress and resilience among physicians during the COVID-19 pandemic. Depression and Anxiety, 37(10), 965-97I. https://doi.org/10.1002/da.23085

O’Donnell, E., Thorne, C., Ahilan, S., Arthur, S., Birkinshaw, S., Butler, D., Dawson, D., Everett, G., Fenner, R., Glenis, V., Kapetas, L., Kilsby, C., Krivtsov, V., Lamond, J., Maskrey, S., O’Donnell, G., Potter, K., Vercruysse, K., Vilcan, T., \& Wright, N. (2020). The blue-green path to urban flood resilience. Blue-Green Systems, 2(I), 28-45. https://doi.org/l0.2166/bgs.2019.199

Ong, H. L., Vaingankar, J. A., Abdin, E., Sambasivam, R., Fauziana, R., Tan, M.-E., Chong, S. A., Goveas, R. R., Chiam, P. C., \& Subramaniam, M. (2018). Resilience and burden in caregivers of older adults: Moderating and mediating effects of perceived social support. BMC Psychiatry, I8(I), 27. https://doi.org/I0.II86/s I2888-0I8-I6I6-z

Polizzi, C., Perry, A., \& Lynn, S. J. (2020). Stress and Coping in the Time of COVID- 19: Pathways to Resilience and Recovery. Clinical Neuropsychiatry, 17(2), 59-62. https://doi.org//0.36I3 I/CN20200204

Pradana, A. A. (2020). Pengaruh kebijakan social distancing pada wabah COVID-19 terhadap kelompok rentan di Indonesia. 7.

Preis, H., Mahaffey, B., Heiselman, C., \& Lobel, M. (2020). Vulnerability and resilience to pandemicrelated stress among U.S. women pregnant at the start of the COVID-19 pandemic. Social Science \& Medicine, 266, I I 3348. https://doi.org/I0.10 I6/j.socscimed.2020.1 I 3348

Puskapik.com. (2020). During the Covid pandemic, the mortality rate for pregnant women has increased. https://www.puskapik.com/ I0496/berita/selama-pandemi-COVID-19-angka-kematian-ibuhamil-meningkat/december I5, 2020.

Rabice, S. R., Altshuler, P. C., Bovet, C., Sullivan, C., \& Gagnon, A. J. (2020). COVID-19 infection presenting as pancreatitis in a pregnant woman: A case report. Case Reports in Women's Health, 27, e00228. https://doi.org/10.1016/j.crwh.2020.e00228

Rostiani, R., Toyib, J. S., \& Khoiriyah, S. (202I). Why do Muslims engage in adaptive worship behavior during the pandemic? The role of protection motives and religiosity. Journal of 
Islamic Marketing, ahead-of-print(ahead-of-print). https://doi.org/ I0. I I08/JIMA-09-2020-026 I

Rowsell, A., Muller, I., Murray, E., Little, P., Byrne, C. D., Ganahl, K., Müller, G., Gibney, S., Lyles, C. R., Lucas, A., Nutbeam, D., \& Yardley, L. (2015). Views of People With High and Low Levels of Health Literacy About a Digital Intervention to Promote Physical Activity for Diabetes: A Qualitative Study in Five Countries. Journal of Medical Internet Research, 17(I0), e230. https://doi.org/10.2196/jmir.4999

Sarafino, E. P., \& Smith, T. W. (20I4). Health Psychology: Biopsychosocial Interactions. John Wiley \& Sons.

Silva, E., Andrade Abdala, G., \& Dias Meira, M. D. (2016). Religiosity and lifestyle of professionals from the family health support centers. O Mundo Da Saúde, 40(3), 310-318. https://doi.org/I0.15343/0104-7809.20164003310318

Sørensen, K., Van den Broucke, S., Fullam, J., Doyle, G., Pelikan, J., Slonska, Z., \& Brand, H. (20I2). (HLS-EU) Consortium Health Literacy Project European, Health literacy and public health: A systematic review and integration of definitions and models. BMC Public Health, 12(I), 80. https://doi.org/10.1 I86//47I-2458-12-80

Stormacq, C., Van den Broucke, S., \& Wosinski, J. (2019). Does health literacy mediate the relationship between socioeconomic status and health disparities? Integrative review. Health Promotion International, 34(5), el-el7. https://doi.org/I0.1093/heapro/day062

Torabizadeh, C., ASadabadi poor, Z., \& Shaygan, M. (2019). The effects of resilience training on the Self-Efficacy of patients with type 2 diabetes: A randomized controlled clinical trial. International Journal of Community Based Nursing \& Midwifery, 7(3). https://doi.org/I0.30476/ijcbnm.2019.44996

Vella, S. A., Swann, C., Batterham, M., Boydell, K. M., Eckermann, S., Ferguson, H., Fogarty, A., Hurley, D., Liddle, S. K., Lonsdale, C., Miller, A., Noetel, M., Okely, A. D., Sanders, T., Schweickle, M. J., Telenta, J., \& Deane, F. P. (202I). An Intervention for Mental Health Literacy and Resilience in Organized Sports. Medicine \& Science in Sports \& Exercise, 53(I), |39-I49. https://doi.org//0.1249/MSS.0000000000002433

World Health Organization. (2020). WHO coronavirus disease (COVID-19) dashboard. https://covid I9.who.int/

Wu, Y., Xu, X., Chen, Z., Duan, J., Hashimoto, K., Yang, L., Liu, C., \& Yang, C. (2020). Nervous system involvement after infection with COVID-19 and other coronaviruses. Brain, Behavior, and Immunity, 87, 18-22. https://doi.org//0.1016/j.bbi.2020.03.03 I

Yeo, S.-E. (20II). Resilience, Character Strengths and Flourishing: A Positive Education Workshop for Singapore Teachers. 84.

Zhang, L., \& Liu, Y. (2020). Potential interventions for novel coronavirus in China: A systematic 


\section{RI}

review. Journal of Medical Virology. https://doi.org/I0.1002/jmv.25707

Zhang, L., Yang, X., Zhao, J., Zhang, W., Cui, C., Yang, F., Ma, R., \& Jia, Y. (2020). Prevalence of prenatal depression among pregnant women and the importance of resilience: A Multi-Site Questionnaire-Based Survey in Mainland China. Frontiers in Psychiatry, II, 374. https://doi.org// 0.3389/fpsyt.2020.00374 